\title{
Internal Control Quality, Corporate Social Responsibility Fulfillment and Enterprise Performance: Evidence from Listed Companies in China's Pharmaceutical Manufacturing Industry
}

\author{
Ziyi Zeng ${ }^{1, *}$, Xi Zhang ${ }^{1}$ \\ ${ }^{1}$ School of Management, Wuhan University Of Technology, Wuhan, China \\ ${ }^{*}$ Corresponding author. Email: 571208625@qq.com
}

\begin{abstract}
Good internal control environment can stabilize the business environment, guard against operational risks, improve enterprise performance. And effective internal controls can provide a good environment for enterprises to enhance their social responsibility fulfillment, thus forming a good reputation effect, enhance corporate performance. Using data from China's pharmaceutical manufacturing industry listed companies, from 2015 to 2019, this paper explored the relationship among internal control quality, corporate social responsibility fulfillment and enterprise performance. The research finds: (1) Internal control quality has a significant positive effect on enterprise performance; (2) Internal control quality is significantly positively correlated with corporate social responsibility fulfillment; (3) Corporate social responsibility fulfillment has a partial mediation effect on the relationship between internal control quality and enterprise performance.
\end{abstract}

Keywords: Internal control quality, Corporate social responsibility, Enterprise performance, Mediating effect

\section{INTRODUCTION}

With the speeding progress of 2030 sustainable development goals in international society and with the new situation of promoting high quality of economy developing, corporate social responsibility work attaches more importance and entails more profound significance. In April 2020, ISO26000 global Chairs of Stakeholder Network summoned a seminar about the role and function of corporate social responsibility in the post-COVID19 era. The seminar proposed that social responsibility has the ability to enhance the resilience of enterprises. In recent years, with the development and expansion of pharmaceutical companies, some drug safety incidents have caused widespread concern in the society. As a link to promote the social and economic development, and a good medicine to protect people's lives and health, pharmaceutical manufacturing enterprises must take their social responsibilities. According to the relevant findings from previous studies, corporate social responsibility fulfillment can be improved through impeccable internal control quality, moderate media oversight, public concern and great economic performance. And internal control can play the role as an important internal governance mechanism. There are the studies finding that the improvement of internal control quality can not only enhance the enterprises competitiveness, but also effectively control enterprise risks, improve enterprise performance and promote the healthy development of the enterprises.

This paper empirically verified the intermediation of social responsibility fulfillment between enterprise internal control quality and enterprise performance, and provides new empirical evidence of the transmission mechanism of the impacts of internal control quality in pharmaceutical enterprises on the enterprise performance. In the meantime, it verified that social responsibility can provide ways to improve enterprise performance and provide a grand reference value of the 
development of Chinese pharmaceutical manufacturing enterprises.

\section{THEORETICAL BACKGROUND AND HYPOTHESES}

\subsection{Internal Control Quality and Enterprise Performance}

As a kind of important management activity, internal controls has a core objective that to improve the efficiency and effectiveness of the enterprise's operation. Ashbaugh (2006) [1] found that if the effectiveness of internal control is low, the cost of equity capital will increase, and enterprise performance will decrease instead. Beneish et al. (2008) [2] used financial reporting disclosure information as an intermediate variable and found that the lack of internal control effectiveness leads to higher cost of equity by depriving the integrity and reliability of accounting information. Willis (2000) [3] argued that: in capital market, effective internal control and objective internal control reporting contribute to increase enterprise value. Jawahar et al. (2001) [4] argued that: effective internal control of a company can improve corporate governance and create a good internal organizational environment to improve enterprise performance. Wang (2015) [5] went further in this area and divided CSR in a more detailed way, arguing that the objects of corporate social responsibility fulfillment should include not only shareholders and employees, but should also include the government and consumers, and through empirical research it is concluded that the social contribution of enterprises to the objects mentioned above is influenced by good or bad internal control of enterprises, and the final empirical results show that a good internal control environment has a facilitating effect on the fulfillment of social responsibility to shareholders as well as the government, but there is no significant effect in terms of employees and consumers. Based on the above analysis, we propose our first hypothesis:

Hypothesis 1 (H1): The improvement of the internal control quality of pharmaceutical manufacturing companies has a positive impact on enterprise performance.

\subsection{Internal Control Quality and Corporate Social Responsibility Fulfillment}

Existing studies indicate that the motivation of companies to fulfill social responsibility includes two aspects, one is internal influencing factors, and the other is external driving factors. Among them, the intrinsic influencing factors mainly focus on the influence of basic internal characteristics of companies such as enterprise size, enterprise performance, financial leverage and the internal control and corporate governance structure of companies, etc. Halebian et al.
(1993) [6] argued that companies can improve their business environment by enhancing the internal control environment, which promotes the fulfillment of social responsibility. Richhard (1999) [7] suggested that building a complete corporate governance structure will have a positive impact on the fulfillment of social responsibility and contribute to the long-term stable development of the company. Aguinis et al. (2012) [8] found that internal control regulates the operation of a company, which leads to the fulfillment of social responsibility. Effective internal control can play a role in correcting the tendency of companies in decision making and promote better fulfillment of social responsibility. Ntim et al. (2013) [9] believe that internal control plays a decisive role in the performance of corporate social responsibilities, and can improve the performance of social responsibilities by improving the level of corporate internal control. Based on the above analysis, we propose our second hypothesis:

Hypothesis 2 (H2): The internal control of pharmaceutical manufacturing companies can promote the fulfillment of corporate social responsibilities.

\subsection{Internal Control Quality, Corporate Social Responsibility Fulfillment and Enterprise Performance}

The ultimate goal of corporate internal control and social responsibility both is to decrease operational risk, to achieve enterprise's sustainable development. Infiltrating the conception of social responsibility to direct the design of internal control, to implement furthest save transaction costs of the enterprises. It is beneficial for enterprises to accomplish their social roles and achieve enterprise value maximization. In the meanwhile, effective internal control is able to supervise the corporate social responsibility fulfillment, achieve sustainable development of enterprises and finally improve enterprise performance. Based on the above analysis, we propose our third hypothesis:

Hypothesis 3 (H3): The corporate social responsibility fulfillment of pharmaceutical manufacturing companies plays an intermediary role in the process of internal control affecting enterprise performance.

\section{RESEARCH DESIGN}

\subsection{Sample Selection}

In this study, data of listed companies in China's pharmaceutical manufacturing industry from 2015 to 2019 were used as samples, and data samples of ST and *ST companies, companies with incomplete data and companies with outliers were deleted. Finally, 835 valid samples were obtained. The data of social responsibility fulfillment comes from Hexun.com's "Corporate Social 
Responsibility Evaluation System for Listed Companies". The internal control data came from the Database of Shenzhen Dibo's Internal Control and Risk Management (DIB). Financial data and company characteristics were derived from the Database of China Stock Market Accounting Research (CSMAR).

\subsection{Definition of Variables}

\subsubsection{Explained Variable}

Referring to previous studies, the indicators for measuring enterprise performance are generally Return on Assets (ROA), Return on Common Stockholders' Equity (ROE), and Tobin-Q value. Among them, ROA is a generalized financial indicator that includes various aspects of enterprise performance such as productivity, sales efficiency, profitability and financial leverage, and is more reliable in comparison. In this paper, we choose the ROA to measure enterprise performance.

\subsubsection{Explanatory Variable}

There are two types of internal control indices that have been publicly released in China: the internal control index of China's listed companies released by the internal control research group of Xiamen University and the internal control of China's listed companies released by Shenzhen Dibo Enterprise Risk Management Technology Co. The internal control index of Xiamen University is mainly designed from the composition of internal control elements and mainly measures the soundness of the internal control system, while the internal control index of Dibo is goal-oriented and focuses more on the effectiveness of internal control operation, which better reflects the relationship between the quality of internal control and the overall performance of the enterprise. Therefore, this paper selects $1 / 100$ of the internal control index published by Dibo as the index to measure the quality of internal control of enterprises.

\subsubsection{Intermediary Variable}

Many scholars have used content analysis and index methods to quantify the quality of social responsibility information disclosure. This kind of self-constructed scoring system is somewhat subjective. Hexun.com's professional evaluation system for social responsibility reports of listed companies provides professional evaluation results of social responsibility of all listed companies, and the research sample is comprehensive and complete, which can effectively avoid the selective bias of the sample. At the same time, the evaluation system divides corporate social responsibility into five modules: shareholder responsibility, employee responsibility, supplier responsibility, environmental responsibility, and charity responsibility, which are basically the same as the classification of corporate social responsibility issued by the Shenzhen Stock Exchange in 2006. Consistent. In view of the authority and the availability of data, this article uses Hexun's corporate social responsibility score to measure corporate social responsibility performance.

\subsubsection{Control Variable}

In addition to the fact that the quality of a firm's internal control and the fulfillment of its social responsibility can have an impact on its enterprise performance, the sample firms' own characteristics can also affect enterprise performance. Therefore, this article controls the following variables:

Enterprise size: from the viewpoint of economies of scale, when other factors are certain, larger enterprises are more risk-resistant and their performance is better.

Asset-liability ratio: The theory of capital structure believes that a reasonable level of debt can reduce agency conflicts between management and shareholders and improve enterprise performance, but excessive financial risks will also erode enterprise performance and corporate competitiveness.

Fixed asset ratio: The fixed asset ratio reflects the phenomenon of whether the fixed assets of the enterprise is idle or not, reflects the operating ability of the enterprise, and will affect the income and growth of the enterprise.

The specific definitions of all variables in this article are shown in Table 1.

Table 1. List of variable definitions

\begin{tabular}{c|c|c|c|}
\hline Variable Type & Name & Code & Calculation Method \\
\hline Explained Variable & enterprise performance & ROA & Net profit after tax by total assets \\
\hline \multirow{2}{*}{ Explanatory Variable } & Internal control quality & ICQ & $\begin{array}{r}1 / 100 \text { of the internal control index } \\
\text { developed by Shenzhen Dibo }\end{array}$ \\
\hline Intermediary Variable & Social responsibility fulfillment & CSRM & Hexun's corporate social responsibility score \\
\hline \multirow{2}{*}{ Control Variable } & Enterprise size & Size & Natural log of total assets \\
\cline { 2 - 4 } & Asset-liability ratio & Fl & Total liabilities divided by total assets \\
\cline { 2 - 4 } & Fixed assets ratio & Fixed & Total fixed assets by total assets \\
\hline
\end{tabular}




\subsection{Definition of Variables}

Taking enterprise performance as the explained variable and internal control quality as the explanatory variable, we constructed Model (1):

$R O A=\beta_{0}+\beta_{11} \times I C Q+\beta_{12} \times \operatorname{Size}+\beta_{13} \times F l+$

$\beta_{14} \times$ Fixed $+\varepsilon$

Taking corporate social responsibility fulfillment as the explained variable and internal control quality as the explanatory variable, we constructed Model (2):

$\operatorname{CSRM}=\beta_{0}+\beta_{21} \times I C Q+\beta_{22} \times$ Size $+\beta_{23} \times F l+$ $\beta_{24} \times$ Fixed $+\varepsilon$

Taking enterprise performance as the explained variable, internal control quality as the explanatory variable and corporate social responsibility fulfillment as the intermediary variable, we constructed Model (3):

$R O A=\beta_{0}+\beta_{31} \times I C Q+\beta_{32} \times C S R M+\beta_{33} \times$ Size + $\beta_{34} \times F l+\beta_{35} \times$ Fixed $+\varepsilon$
Table 2 provides the descriptive statistics of the variables. Among them, the overall level of enterprise performance indicators (ROA) in the pharmaceutical manufacturing industry is not high, and the data range is $[-0.744,0.340]$, indicating that there are certain differences in enterprise performance of different companies. Internal control quality (ICQ) is $1 / 100$ of Dibo's internal control index, with the minimum of 2.917 and the maximum of 8.385 , indicating that the internal control quality of the sample companies are quite different. The minimum value of the social responsibility fulfillment index (CSRM) is -10.050 , the maximum value is 87.020 , and the average value is 25.690 , indicating that the social responsibility fulfillment of pharmaceutical manufacturing listed companies are very different, plus even the grades of a few enterprises fall into minus, and may arouse harm to the benefits of stakeholders due to the failure to implement social responsibility. In addition, it can be seen from the data in the table that the debt levels and fixed asset ratios of listed companies in the pharmaceutical manufacturing industry are quite different.

\section{EMPIRICAL TESTING}

\subsection{Descriptive Statistics}

Table 2. Descriptive statistics

\begin{tabular}{l|l|l|l|l|l}
\hline Variables & $\mathrm{N}$ & Min & Max & Mean & Std. \\
\hline ROA & 835 & -0.744 & 0.340 & 0.070 & 0.075 \\
\hline ICQ & 835 & 2.917 & 8.385 & 6.486 & 0.692 \\
\hline CSRM & 835 & -10.050 & 87.020 & 25.690 & 11.609 \\
\hline Size & 835 & 19.883 & 25.056 & 22.084 & 0.955 \\
\hline FI & 835 & 0.031 & 0.886 & 0.302 & 0.166 \\
\hline Fixed & 835 & 0.019 & 0.622 & 0.214 & 0.111 \\
\hline
\end{tabular}

Table 3. Pearson' s correlation coefficients for the full sample

\begin{tabular}{l|l|l|l|l|l|l|}
\hline Variables & ROA & ICQ & CSRM & Size & FI & Fixed \\
\hline ROA & 1 & & & & & \\
\hline ICQ & $0.384^{\star \star *}$ & 1 & & & & \\
\hline CSRM & $0.469^{\star \star \star}$ & $0.268^{\star \star \star}$ & 1 & & & \\
\hline Size & 0.020 & $-0.085^{\star \star \star}$ & $0.155^{\star \star \star}$ & 1 & & \\
\hline FI & $-0.402^{\star \star \star}$ & $-0.114^{\star \star \star}$ & $-0.208^{\star \star \star}$ & $0.339^{\star \star \star}$ & 1 & \\
\hline Fixed & $-0.208^{\star \star \star}$ & $-0.101^{\star \star \star}$ & $-0.115^{\star \star \star}$ & $-0.165^{\star \star \star}$ & $0.151^{\star \star *}$ & 1 \\
\hline
\end{tabular}

Note: *,***** indicate significance at the $10 \%, 5 \%$, and $1 \%$ levels, respectively, and the same below.

\subsection{Correlation Analysis}

In order to test the correlation between internal control quality (ICQ), social responsibility fulfillment (CSRM) and enterprise performance (ROA), this study conducted Pearson correlation analysis on the main variables. Table 2 provides the correlation coefficients between the variables. According to the result, internal control quality (ICQ) and enterprise performance (ROA) are positively correlated at $1 \%$ significance level, which preliminarily proves that internal control quality (ICQ) can promote enterprise performance 
(ROA). Internal control quality (ICQ) and social responsibility fulfillment (CSR) are also positively correlated at the level of $1 \%$, indicating that the improvement of internal control quality of pharmaceutical companies can promote the fulfillment of their social responsibilities.

In addition, the correlation coefficient between every two variables is less than 0.5 , indicating that there is no serious multicollinearity problem. Regression analysis can be performed.

\subsection{Analysis of Regression Results}

\subsubsection{Internal Control Quality and Corporate Social Responsibility Fulfillment}

Table 4 provides the regression results of each model. According to it, model 1 tested the effect internal control quality (ICQ) on enterprise performance (ROA). Among it, $\mathrm{F}=89.578$ and remarkable and $\mathrm{Adj}-\mathrm{R}^{2}=$ 0.298 , which indicates the relatively high degree of fit existing between each variable and Model 1. The regression coefficient $\left(\beta_{11}\right)$ between Internal control quality (ICQ) and enterprise performance (ROA) is $0.035, \mathrm{t}=10.870$, and significant at the $1 \%$ level, which indicates that when listed pharmaceutical manufacturing companies strengthen corporate internal control, the improvement of enterprise performance can be promoted, and hypothesis $1(\mathrm{H} 1)$ is true.

\subsubsection{Internal Control Quality and Corporate Social Responsibility Fulfillment}

Model 2 tested the effect internal control quality (ICQ) on social responsibility fulfillment (CSRM). Among it, $F=36.012$ and remarkable and $A d j-R^{2}=$
0.144 , which indicates the relatively high degree of fit existing between each variable and Model 2. The regression coefficient $\left(\beta_{21}\right)$ between Internal control quality (ICQ) and social responsibility fulfillment $(\mathrm{CSRM})$ is $3.672, \mathrm{t}=6.713$, significant at $1 \%$ confidence level which indicates that pharmaceutical manufacturing companies improving the internal control quality is beneficial to promote enterprises to undertake social responsibility, and hypothesis $2(\mathrm{H} 2)$ is true.

\subsubsection{Internal Control Quality, Corporate Social Responsibility Fulfillment and Enterprise Performance}

According to the three-step test for mediating effect of Zhonglin Wen, the regression coefficients of explanatory variable in model 1 and model 2 are all significant at the $1 \%$ level, and it passes the first two steps of the mediating effect test. The regression result of Model 3 shows that $F=105.985$, Adj- $R^{2}=0.386$. Compared to Model 1, Adj- $\mathrm{R}^{2}$ increased by 0.088 , and the data fitting degree is better. The coefficient $\left(\beta_{31}\right)$ of internal control quality (ICQ) is 0.027 . Contrasted to the coefficient $\left(\beta_{11}\right)$ of internal control quality (ICQ) in Model(1), it decreased by 0.008 . The coefficient $\left(\beta_{32}\right)$ of corporate social responsibility fulfillment (CSRM) is 0.002 . Both $\beta_{31}$ and $\beta_{32}$ are significantly positive at the $1 \%$ confidence level, which passes the third step of the mediating effect test. It shows that when companies improve the internal control quality, it helps to promote their social responsibility fulfillment. So, enterprise performance is improved, namely, social responsibility fulfillment partially plays a mediating role in the relationship between internal control quality and enterprise performance. And hypothesis 3 (H3) is true.

Table 4. Regression coefficient and results of each model

\begin{tabular}{|c|c|c|c|}
\hline \multirow{2}{*}{ Variables } & Model (1) & Model (2) & Model (3) \\
\hline & ROA & CSRM & $\mathrm{ROA}$ \\
\hline ICQ & $\begin{array}{c}\beta_{11}=0.035^{\star \star \star} \\
(10.870)\end{array}$ & $\begin{array}{c}\beta_{21}=3.672^{\star \star \star} \\
(6.713)\end{array}$ & $\begin{array}{c}\beta_{31}=0.027^{\star * \star} \\
(8.833)\end{array}$ \\
\hline CSRM & & & $\begin{array}{c}\beta_{32}=0.002^{\star \star \star} \\
(10.962)\end{array}$ \\
\hline Size & $\begin{array}{l}0.008^{* * *} \\
(3.359)\end{array}$ & $\begin{array}{c}2.667^{\star * *} \\
(6.223)\end{array}$ & $\begin{array}{l}0.003 \\
(1.197) \\
\end{array}$ \\
\hline $\mathrm{Fl}$ & $\begin{array}{l}-0.175^{\star \star \star} \\
(-12.123)\end{array}$ & $\begin{array}{c}-17.861^{\star \star \star} \\
(-7.231) \\
\end{array}$ & $\begin{array}{l}-0.138^{\star \star \star} \\
(-9.905)\end{array}$ \\
\hline Fixed & $\begin{array}{l}-0.067^{\star \star \star} \\
(-3.274) \\
\end{array}$ & $\begin{array}{c}-1.923 \\
(-0.549) \\
\end{array}$ & $\begin{array}{l}-0.063^{\star \star \star} \\
(-3.292) \\
\end{array}$ \\
\hline $\mathrm{R}^{2} \_\mathrm{Adj}$ & 0.298 & 0.144 & 0.386 \\
\hline $\mathrm{F}$ & $89.578^{\star \star \star}$ & $36.012^{* * *}$ & $105.985^{\star * * *}$ \\
\hline
\end{tabular}

fn terms of the control variables, the regression results of asset-liability ratio and fixed assets ratio are 
influence of asset-liability ratio and fixed assets ratio on enterprise performance significant and stable, while the influence of enterprise size on enterprise performance in the selected data is less significant.

\subsection{Testing for Robustness}

To guarantee the reliability of the research results, this text performed robustness test by substitution variables. We substitute measurement index of enterprise performance for net assets income rate (ROE). The results are shown in Table 5. In Model 1, the regression coefficient of internal control quality and enterprise performance is 0.059 and significant at the $1 \%$ level; in Model 2, the regression coefficient of internal control quality and enterprise performance is 3.672 and significant at the $1 \%$ level; in Model 3, the regression coefficients of internal control quality and enterprise performance and social responsibility fulfillment are separately $0.046,0.003$, and both are significant at the $1 \%$ level, and $\beta_{31}<\beta_{11}$, Adj- $\mathrm{R}^{2}$ in Model $3>\operatorname{Adj}-\mathrm{R}^{2}$ in Model 1. The research conclusion is consistent with the above conclusions and the model construction in this text has robustness.

Table 5. Robustness test

\begin{tabular}{|c|c|c|c|}
\hline \multirow{2}{*}{ Variables } & Model (1) & Model (2) & Model (3) \\
\hline & ROE & CSRM & ROA \\
\hline ICQ & $\begin{array}{c}\beta_{11}=0.059 * * * \\
(10.574)\end{array}$ & $\begin{array}{c}\beta_{21}=3.672^{\star \star \star} \\
(6.713)\end{array}$ & $\begin{array}{c}\beta_{31}=0.046^{\star \star *} \\
(8.621)\end{array}$ \\
\hline CSRM & & & $\begin{array}{c}\beta_{32}=0.003^{* * *} \\
(10.041)\end{array}$ \\
\hline Size & $\begin{array}{l}0.014^{\star \star \star} \\
(3.270) \\
\end{array}$ & $\begin{array}{c}2.667^{\star \star \star} \\
(6.223) \\
\end{array}$ & $\begin{array}{l}0.005 \\
(1.263) \\
\end{array}$ \\
\hline $\mathrm{Fl}$ & $\begin{array}{l}-0.158^{\star \star \star} \\
(-6.321)\end{array}$ & $\begin{array}{c}-17.861^{\star \star \star} \\
(-7.231)\end{array}$ & $\begin{array}{l}-0.099 * * * \\
(-4.036)\end{array}$ \\
\hline Fixed & $\begin{array}{l}-0.074^{\star \star \star} \\
(-2.092)\end{array}$ & $\begin{array}{c}-1.923 \\
(-0.549)\end{array}$ & $\begin{array}{l}-0.068^{* \star *} \\
(-2.022)\end{array}$ \\
\hline $\mathrm{R}^{2} \_$Adj & 0.190 & 0.144 & 0.277 \\
\hline $\mathrm{F}$ & $50.057^{\star \star \star}$ & $36.012^{\star \star \star}$ & $65.029 * \star \star$ \\
\hline
\end{tabular}

\section{CONCLUSION}

Based on the data of listed companies in China's pharmaceutical manufacturing industry from 2015 to 2019, this article explores the relationship between internal control quality, social responsibility fulfillment and enterprise performance through empirical research. The main conclusions are as follows:

(1) The internal control quality (ICQ) of pharmaceutical manufacturing companies can effectively promote the improvement of enterprise performance (ROA). The supervision and control of operations by internal control can increase the degree of professional management, increase operational efficiency and improve enterprise performance.

(2) The internal control quality (ICQ) of pharmaceutical manufacturing companies plays a significant role in promoting corporate social responsibility (CSRM). The establishment of an efficient internal control system for an enterprise can promote the company to actively fulfilits social responsibilities.
(3) The fulfillment of social responsibilities of pharmaceutical manufacturing companies has played an intermediary effect between internal control quality (ICQ) and enterprise performance (ROA), that is, under other conditions unchanged, internal control quality can improve enterprise performance through social responsibility fulfillment. Internal control can promote enterprises to assume social responsibility, and undertaking social responsibility can help enterprises gain recognition and support from the society, bring soft power to enterprises, and become an additional advantage of internal control to improve enterprise performance.

The study enriches the research on internal control and enterprise performance and provides empirical data to improve the corporate performance of listed pharmaceutical companies in China. Enterprises should further strengthen the quality of internal control to ensure legal compliance of their operations. At the same time, this paper verifies that the fulfillment of social responsibility of pharmaceutical enterprises provides a way to improve their enterprise performance and contributes to the enhancement of social responsibility awareness of pharmaceutical enterprises. The managers 
of enterprises should change their mindset, not only focus on "short-term interests" and treat social responsibility as a cost, but also actively fulfill their social responsibility and strive to improve their own image to achieve sustainable development.

\section{REFERENCES}

[1] H. Ashbaugh-Skaife, D. W. Collins, R. LaFond, "The effects of corporate governance on firms'credit ratings," Journal of Accounting and Economics, vol. 6, no. 1-2, pp. 203-243, 2006.

[2] M. D. Beneish, M. B. Billings, L. D. Hodder, "Internal Control Weaknesses and Information Uncertainty," Accounting Review, vol. 83, no. 3, pp. 665-703, 2008.

[3] A. Willis, "Tectonic control of nested sequence architecture in the Sego Sandstone, Neslen Formation and Upper Castlegate Sandstone (Upper Cretaceous), Sevier Foreland Basin, Utah, USA," Sedimentary Geology, vol. 136, no. 3, pp. 277-317, 2000.

[4] I. M. Jawahar, G. L. Mclaughlin, "Toward a Descriptive Stakeholder Theory: An Organizational Life Cycle Approach," Academy of Management Review, vol. 26, no. 3, pp. 397-414, 2001.

[5] Y. Wang, M. Tang, X. Yu, "Can the High Quality of Internal Control Promote the Fulfillment of Corporate Social Responsibility in Energy Enterprises," Atlantis Press, pp. 526-530, 2015.

[6] J. Haleblian, S. Finkelstein, "Top Management Team Size, CEO Dominance, and Firm Performance: The Moderating Roles of Environmental Turbulence and Discretion," Academy of Management Journal, vol. 36, no. 4, pp. 844-863, 1993.

[7] R. A. Johnson, D. W. Greening, "The Effects of Corporate Governance and Institutional Ownership Types on Corporate Social Performance," Academy of Management Journal, vol. 42, no. 5, pp. 564576, 1999.

[8] H. Aguinis, A. Glavas, "What We Know and Don't Know About Corporate Social Responsibility: A Review and Research Agenda," Journal of Management, vol. 38, no. 4, pp. 932-968, 2012.

[9] G. Ntim, T. Soobaroyen, "Corporate Governance and Performance in Socially Responsible Corporations:New Empirical Insights from a Neo-
Institutional Framework," Corporate Governance: An International Review, vol. 21, no. 5, pp. 468494, 2013 